\title{
Physically mixed ZnO and skeletal NiMo for one-pot reforming-hydrogenolysis of glycerol to 1,2-propanediol
}

\author{
HU Jiye a , LIU Xiaoyu a, FAN Yiqiu a, XIE Songhai a, PEI Yan a, QIAO Minghua a,*, FAN Kangnian a, \\ ZHANG Xiaoxin ${ }^{\mathrm{b}}$, ZONG Baoning b,\# \\ a Department of Chemistry and Shanghai Key Laboratory of Molecular Catalysis and Innovative Materials, Fudan University, Shanghai 200433, China \\ ${ }^{\mathrm{b}}$ State Key Laboratory of Catalytic Materials and Reaction Engineering, Research Institute of Petroleum Processing, Beijing 100083, China
}

\section{A R T I C L E I N F O}

\section{Article history:}

Received 20 December 2012

Accepted 29 January 2013

Published 20 May 2013

\section{Keywords:}

Glycerol

Hydrogenolysis

Zinc oxide

Nickel

Molybdenum

Synergistic effect

\begin{abstract}
A B S T R A C T
The one-pot aqueous phase reforming (APR) and hydrogenolysis of glycerol to 1,2-propanediol (PDO) was catalyzed by physically mixed skeletal NiMo and zinc oxide catalysts in a continuous flow fixed-bed reactor without the aid of added $\mathrm{H}_{2}$. The skeletal NiMo catalyst alone is highly active towards glycerol but the selectivity for 1,2-PDO is only moderate. Physically mixing of $\mathrm{MgO}, \mathrm{SiO}_{2}$, $\mathrm{Al}_{2} \mathrm{O}_{3}, \mathrm{HZSM}-5, \mathrm{TiO}_{2}, \mathrm{ZrO}_{2}$, or $\mathrm{CeO}_{2}$ as a cocatalyst with skeletal NiMo was detrimental to the conversion of glycerol and yield of 1,2-PDO. However, physically mixing with $\mathrm{ZnO}$ gave an advantageous promoting effect on both the catalytic activity and selectivity for 1,2-PDO, and gave a 1,2-PDO yield of $52.0 \%$, which is higher than that obtained with noble metal catalysts for the APR-hydrogenolysis of glycerol. The synergistic effect between physically mixed $\mathrm{ZnO}$ and skeletal NiMo was attributed to in situ enhancement of the Lewis acidity of $\mathrm{ZnO}$ by chemisorbed $\mathrm{CO}_{2}$ from the APR of glycerol on skeletal NiMo, which benefited both the dehydration of glycerol to acetol on $\mathrm{ZnO}$ and the hydrogenation of acetol to 1,2-PDO on skeletal NiMo.
\end{abstract}

(c) 2013, Dalian Institute of Chemical Physics, Chinese Academy of Sciences. Published by Elsevier B.V. All rights reserved.

\section{Introduction}

1,2-Propanediol (PDO) has extensive applications as a functional fluid, and in the production of daily essential tools, polyesters, and polyurethanes [1,2]. It is currently manufactured by the catalytic hydration of propylene oxide [3], which is a process that uses rapidly depleting fossil fuels. Many researchers have studied the catalytic transformation of glycerol to 1,2-PDO under $\mathrm{H}_{2}$ in a batch reactor [4-6]. This process is regarded as more promising than the traditional petrochemical route because glycerol is now abundantly available as the main by- product in the production of biodiesel [7-9]. In general, the production of 10 ton of biodiesel is accompanied by the production of 1 ton of glycerol. However, due to the low solubility of $\mathrm{H}_{2}$ in a glycerol/water solution [10], a relatively high $\mathrm{H}_{2}$ pressure (5-8 $\mathrm{MPa}$ ) is needed to achieve a high yield of 1,2-PDO [11-13].

In recent years, researchers have explored the production of 1,2-PDO from glycerol under an inert atmosphere [14-17] using $\mathrm{H}_{2}$ generated by the aqueous phase reforming (APR) of some of the glycerol as a hydrogen source for the hydrogenolysis of glycerol (Scheme 1). The advantages of this one-pot APR-

\footnotetext{
* Corresponding author. Tel: +86-21-55664679; Fax: +86-21-55665701; E-mail: mhqiao@fudan.edu.cn

\# Corresponding author. Tel/Fax: +86-10-82368011; E-mail: zongbn.ripp@sinopec.com

This work was supported by the Program for New Century Excellent Talents in Universities (NCET-08-0126), the National Basic Research Program of China (973 Program, 2012CB224804), the National Natural Science Foundation of China (21073043), Shanghai Science and Technology Committee (10JC1401800, 08DZ2270500), and Shanghai Key Laboratory of Rare Earth Functional Materials, Shanghai Normal University.

DOI: 10.1016/S1872-2067(12)60543-9 | http://www.sciencedirect.com/science/journal/18722067 | Chin. J. Catal., Vol. 34, No. 5, May 2013
} 


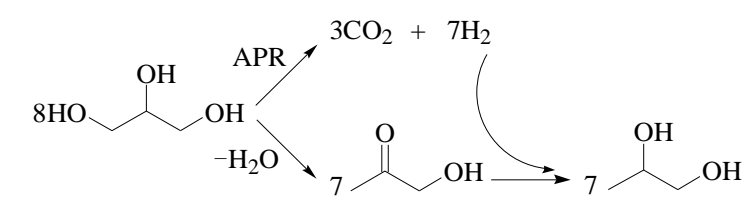

Scheme 1. Reaction pathway of the one-pot APR-hydrogenolysis of glycerol to 1,2-PDO.

hydrogenolysis are: (1) the reaction is performed under an inert atmosphere, which avoids the use of highly flammable $\mathrm{H}_{2}$ produced from fossil fuels, thus ensuring a safer and more sustainable process; and (2) the reaction pressure is lower than that which use externally supplied $\mathrm{H}_{2}$ as the reactant, thus leading to improved operation safety and economics [16]. In this way, a greener production of 1,2-PDO from glycerol and water is obtained.

In a pioneering work, Wawrzetz et al. [17] explored the one-pot APR-hydrogenolysis of glycerol in a continuous flow fixed-bed reactor over a $\mathrm{Pt} / \mathrm{Al}_{2} \mathrm{O}_{3}$ catalyst. They investigated the detailed reaction network by systematic experimental design. The continuous production of 1,2-PDO from glycerol without externally supplied $\mathrm{H}_{2}$ is highly attractive from an industrial point of view. However, concerning its practical application, hardly any work has been devoted to enhancing the selectivity for 1,2-PDO. Moreover, there has been a surprising dearth of the development of an inexpensive non-noble metal catalyst for this promising one-pot reaction process [18].

This paper reports our endeavors to improve the selectivity for 1,2-PDO at a high conversion of glycerol using a physically mixed bifunctional catalyst system in a continuous flow fixed-bed reactor in the absence of external $\mathrm{H}_{2}$. A skeletal NiMo catalyst described in our previous work $[19,20]$ was employed as the primary catalyst since this catalyst is active in both the APR of polyol $[19,21]$ and the saturation of the $C=0$ group $[20,22]$. On the other hand, it has been reported that metal oxides, resins, or sulphated zirconia as cocatalyst can improve the catalytic performance of some supported metal catalysts in the hydrogenolysis of glycerol under $\mathrm{H}_{2}[8,9,11]$. In this work, we first evaluated the catalytic performance of a physical mixture of skeletal NiMo with various conventional oxides for the one-pot APR-hydrogenolysis of glycerol. After identifying ZnO as effective in enhancing the production of 1,2-PDO, we then optimized the $\mathrm{ZnO} / \mathrm{NiMo}$ ratio and investigated its role in the mechanism. An interpretation of the synergistic effect between $\mathrm{ZnO}$ and skeletal NiMo in the one-pot APR-hydrogenolysis of glycerol to 1,2-PDO is presented.

\section{Experimental}

\subsection{Catalyst preparation}

A mixture of metallic Ni (40\%), Mo (10\%), and Al (50\%) powders, with the weight percents shown in the brackets, was melted at $1573 \mathrm{~K}$ under $\mathrm{Ar}$. $\mathrm{A} \mathrm{Ni}_{40} \mathrm{Mo}_{10} \mathrm{Al}_{50}$ alloy ribbon with a cross section of $0.02 \mathrm{~mm} \times 5 \mathrm{~mm}$ was obtained by a single roller melt-spinning method. The brittle alloy ribbon was ground to 60-80 mesh for alkali leaching. Then, $1.0 \mathrm{~g}$ of the alloy powder was dealuminated by $10 \mathrm{ml}$ of $5 \mathrm{~mol} / \mathrm{L} \mathrm{NaOH}$ aqueous solution at $363 \mathrm{~K}$ for $1 \mathrm{~h}$ under gentle stirring [23]. The resulting black NiMo powder was washed to neutrality with deionized water. For activity testing, the freshly prepared catalyst was loaded into a tubular reactor with the protection of deionized water to avoid oxidation. The mass ratio of $\mathrm{Ni}$ to Mo in the skeletal NiMo catalyst was 37:1, which was determined by inductively coupled plasma atomic emission spectroscopy. Its specific surface area, pore volume, and pore diameter determined by $\mathrm{N}_{2}$ physisorption were $92 \mathrm{~m}^{2} / \mathrm{g}, 0.096 \mathrm{~cm}^{3} / \mathrm{g}$, and $4.18 \mathrm{~nm}$, respectively.

$\mathrm{SiO}_{2}$ (S5505-100G, Sigma-Aldrich), $\mathrm{Al}_{2} \mathrm{O}_{3}$ (AR, Sinopharm), and $\mathrm{TiO}_{2}$ (P25, AR, Sinopharm) were used as received. MgO, $\mathrm{CeO}_{2}$, and $\mathrm{ZnO}$ were prepared by the thermal decomposition of pre-dried $\mathrm{Mg}\left(\mathrm{NO}_{3}\right)_{2} \cdot 6 \mathrm{H}_{2} \mathrm{O}, \mathrm{Ce}\left(\mathrm{NO}_{3}\right)_{3} \cdot 6 \mathrm{H}_{2} \mathrm{O}$, and $\mathrm{Zn}\left(\mathrm{NO}_{3}\right)_{2} \cdot 6 \mathrm{H}_{2} \mathrm{O}$ (AR, Sinopharm), respectively, in air at a heating rate of 10 $\mathrm{K} / \mathrm{min}$ from room temperature to $773 \mathrm{~K}$ and held for $4 \mathrm{~h} . \mathrm{ZrO}_{2}$ was prepared by adding $25 \mathrm{wt} \%$ ammonia (AR, Sinopharm) aqueous solution to $0.5 \mathrm{~mol} / \mathrm{L} \mathrm{ZrOCl}_{2}$ (AR, Sinopharm) aqueous solution and refluxing for $48 \mathrm{~h}$. The resulting white powder was calcined in air at a heating rate of $10 \mathrm{~K} / \mathrm{min}$ from room temperature to $873 \mathrm{~K}$ and held for $5 \mathrm{~h}$. HZSM- 5 was prepared by the procedure described by Haw et al. [24] with a Si/Al molar ratio of 20 .

\subsection{Characterization}

X-ray diffraction patterns (XRD) were acquired on a Bruker D8 Advance X-ray diffractometer using Ni-filtered $\mathrm{Cu} K_{\alpha}$ radiation $(\lambda=0.15418 \mathrm{~nm})$ with a scanning range $(2 \theta)$ of $30^{\circ}-90^{\circ}$. The tube voltage was $40 \mathrm{kV}$ and the current was $40 \mathrm{~mA}$.

X-ray photoelectron spectroscopy (XPS) was performed on a Perkin Elmer PHI5000C spectrometer with $\mathrm{Mg} K_{\alpha}$ radiation ( $h v=1253.6 \mathrm{eV}$ ) as the excitation source. The sample, protected by absolute ethanol, was pressed into a self-supporting disc, mounted on the sample plate, and degassed in the pretreatment chamber under vacuum for $4 \mathrm{~h}$ at room temperature. The sample was then transferred to the analysis chamber with a background pressure better than $3 \times 10^{-7} \mathrm{~Pa}$. Binding energy (BE) values were referenced to the $\mathrm{C} 1 \mathrm{~s}$ level of contaminant carbon at $284.6 \mathrm{eV}$.

The active surface area of the skeletal NiMo was determined by pulsed $\mathrm{H}_{2}$ adsorption. After it was treated at $508 \mathrm{~K}$ for $2 \mathrm{~h}$ under flowing Ar, the sample was cooled down to room temperature under Ar. Then, $\mathrm{H}_{2}$ pulses were injected until the eluted peak areas of consecutive pulses monitored by a thermal conductivity detector (TCD) became constant. The active surface area of the skeletal NiMo, $21 \mathrm{~m}^{2} / \mathrm{g}$, was derived from the amount of $\mathrm{H}_{2}$ adsorbed by assuming a $\mathrm{H} / \mathrm{Ni}_{\mathrm{s}}$ stoichiometry of 1 and a surface area of $6.5 \times 10^{-20} \mathrm{~m}^{2}$ per $\mathrm{Ni}$ atom [25], which falls well within the values reported for Raney-type Ni catalysts [26].

Temperature-programmed desorption of $\mathrm{NH}_{3}\left(\mathrm{NH}_{3}-\mathrm{TPD}\right)$ 
was conducted as follows. The oxide was activated in He flow at $673 \mathrm{~K}$ for $1 \mathrm{~h}$ and then saturated by flowing a $10 \mathrm{vol} \% \mathrm{NH}_{3}-90$ vol\% He mixed gas at $393 \mathrm{~K}$ for $1 \mathrm{~h}$. The sample was purged with He for $2 \mathrm{~h}$ to remove gaseous and physisorbed $\mathrm{NH}_{3}$ and then heated at a ramping rate of $20 \mathrm{~K} / \mathrm{min}$. The desorbed $\mathrm{NH}_{3}$ was monitored by TCD.

\subsection{Activity testing and product analysis}

The continuous flow fixed-bed reactor for the one-pot APR-hydrogenolysis of glycerol was used following the procedure of Shabaker et al. [27]. An aqueous solution containing 10 $w t \%$ glycerol was fed into the reactor in an upflow configuration. The reaction was conducted at $508 \mathrm{~K}$ and pressure of 3.1 MPa regulated by Ar, which was lower than the $\mathrm{H}_{2}$ pressure required for the hydrogenolysis of glycerol using external $\mathrm{H}_{2}$ [11-13]. During the reaction, the gas products were analyzed by an online gas chromatograph (GC102M). $\mathrm{H}_{2}$ and $\mathrm{CO}_{2}$ were separated by a $0.5 \mathrm{~nm}$ molecular sieve packed column and measured by a TCD. Light alkanes were separated by a Porapak $\mathrm{R}$ packed column and measured by a flame ionization detector (FID). Liquid phase products were condensed and analyzed on a GC9560 gas chromatograph fitted with a CP-Wax 52 CB capillary column $(30 \mathrm{~m} \times 0.25 \mathrm{~mm} \times 0.25 \mu \mathrm{m})$ and an FID. The liquid products were also measured by GC-MS (Finnigan Voyager) with an HP-5 capillary column. The carbon balance was within $\pm 5 \%$ for all reaction runs.

\section{Results and discussion}

\subsection{APR-hydrogenolysis of glycerol over skeletal NiMo catalyst}

Figure 1 presents the XRD pattern of the skeletal NiMo catalyst. There were diagnostic (111), (200), and (220) reflections of $\mathrm{Ni}$ at $2 \theta$ of $44.3^{\circ}, 51.8^{\circ}$, and $76.3^{\circ}$ (JCPDS 04-0850), respectively. Based on the Scherrer equation and the broadening of the $\mathrm{Ni}(111)$ peak, the average crystallite size of $\mathrm{Ni}$ was estimated to be $3.7 \mathrm{~nm}$. No feature due to an Mo species was found, indicating their high dispersion in the catalyst.

Figure 2 shows the Ni $2 p$ and Mo $3 d$ XPS profiles of the skeletal NiMo catalyst. Ni was predominantly in the metallic state shown by the $\mathrm{Ni} 2 p_{3 / 2} \mathrm{BE}$ of $852.7 \mathrm{eV}$ [28]. The Mo $3 d$ profile was deconvoluted into three components with $3 d_{5 / 2}$ BEs of 228.0, 229.3, and $232.6 \mathrm{eV}$, which were assigned to metallic Mo,

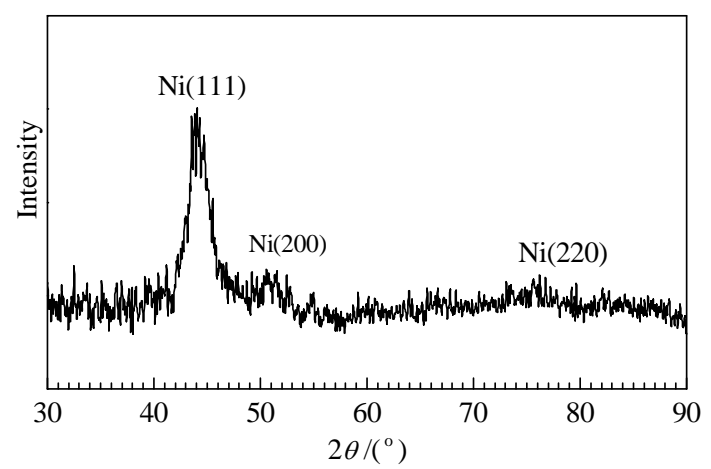

Fig. 1. XRD pattern of the skeletal NiMo catalyst.
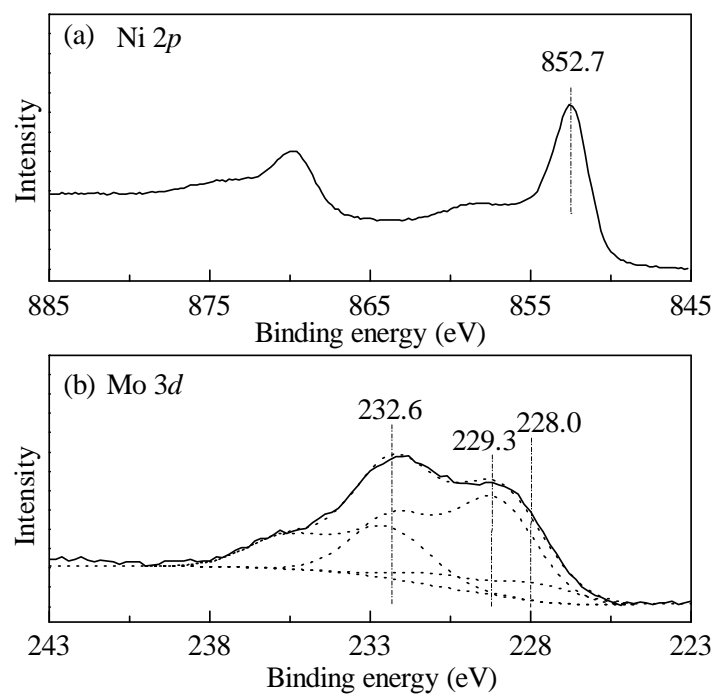

Fig. 2. Ni $2 p$ (a) and Mo $3 d$ (b) XPS profiles of the skeletal NiMo catalyst.

$\mathrm{MoO}_{2}$, and $\mathrm{MoO}_{3}$, respectively [28]. The molybdenum oxides were formed during the alkali leaching [29].

Entry 1 in Table 1 shows the catalytic activity of the one-pot APR-hydrogenolysis of glycerol over the skeletal NiMo catalyst. Glycerol was almost completely converted under the reaction condition used. There were both APR products $\mathrm{CH}_{2}, \mathrm{CO}_{2}$, and light alkanes) and dehydration/hydrogenation (hydrogenolysis) products (acetol and 1,2-PDO) of glycerol. Ethanol and other liquid products were detected in smaller amounts. On this catalyst, the carbon-based selectivities to gas products, acetol, and 1,2-PDO were $40.9 \%, 8.5 \%$, and $32.0 \%$, respectively. Since the skeletal NiMo catalyst is not only active in converting glycerol, but also moderately selective for 1,2-PDO, it gives a solid basis for the development of a more selective catalyst by suitable catalyst modification.

\subsection{APR-hydrogenolysis of glycerol over the ZnO-NiMo mixture catalyst}

Guided by the findings that the mixing of a catalyst with a second component can greatly influence the product distribution [8,30-32], we physically mixed the NiMo catalyst with $\mathrm{MgO}, \mathrm{SiO}_{2}, \mathrm{Al}_{2} \mathrm{O}_{3}, \mathrm{HZSM}-5, \mathrm{TiO}_{2}, \mathrm{ZrO}_{2}, \mathrm{CeO}_{2}$, or $\mathrm{ZnO}$, with their diverse acid properties, as a cocatalyst for the one-pot APR-hydrogenolysis of glycerol to 1,2-PDO. Figure 3 presents the $\mathrm{NH}_{3}$-TPD profiles of these oxides. The total acid amounts are summarized in Table 2. As shown in Fig. 4, except for $\mathrm{ZnO}$, the conversion of glycerol decreased to varying degrees with these oxide-NiMo mixture catalysts, and consequently the yields of 1,2-PDO were also decreased. In contrast, when $\mathrm{ZnO}$ was used as the cocatalyst, there was a promoting effect on the catalytic performance. Entries 2-4 in Table 1 show that the conversion of glycerol with the $\mathrm{ZnO}$-NiMo mixture catalysts remained essentially the same as that with just the skeletal NiMo catalyst, while the selectivity for 1,2-PDO was increased significantly and the selectivity for gas products was decreased remarkably. When the $\mathrm{ZnO} / \mathrm{NiMo}$ mass ratio was increased from 0 to 2.0 , the yield of 1,2-PDO increased from $31.7 \%$ to 
Table 1

Catalytic activity in one-pot APR-hydrogenolysis of glycerol.

\begin{tabular}{|c|c|c|c|c|c|c|c|c|}
\hline \multirow{2}{*}{ Entry } & \multirow{2}{*}{ Catalyst } & \multirow{2}{*}{$\begin{array}{c}\text { Conversion } \\
(\%)\end{array}$} & \multirow{2}{*}{$\begin{array}{c}\text { Yield of 1,2-PDO } \\
(\%)\end{array}$} & \multicolumn{5}{|c|}{ Carbon-based product selectivity a (\%) } \\
\hline & & & & Gas $^{b}$ & Ethanol & Acetol & 1,2-PDO & Others ${ }^{\circ}$ \\
\hline 1 & NiMo & 99.1 & 31.7 & 40.9 & 13.5 & 8.5 & 32.0 & 5.1 \\
\hline 2 & $\mathrm{ZnO}-\mathrm{NiMo}(0.5)^{\mathrm{d}}$ & 98.7 & 38.3 & 30.8 & 8.3 & 12.6 & 38.8 & 9.5 \\
\hline 3 & $\mathrm{ZnO}-\mathrm{NiMo}(1.0)^{\mathrm{d}}$ & 99.4 & 46.1 & 23.1 & 6.8 & 15.5 & 46.4 & 8.2 \\
\hline 4 & $\mathrm{ZnO}-\mathrm{NiMo}(2.0)^{\mathrm{d}}$ & 98.9 & 49.6 & 16.5 & 5.3 & 17.1 & 50.2 & 10.9 \\
\hline 5 & $\mathrm{ZnO}-\mathrm{NiMo}(2.0)^{\mathrm{d}, \mathrm{e}}$ & 98.7 & 52.0 & 12.9 & 4.6 & 18.8 & 52.7 & 11.0 \\
\hline 6 & $\mathrm{ZnO}^{\mathrm{f}}$ & 0.0 & - & - & - & - & - & - \\
\hline 7 & $\mathrm{ZnO}+\mathrm{NiMog}$ & 98.5 & 30.2 & 38.3 & 14.7 & 8.9 & 30.7 & 7.4 \\
\hline 8 & $\mathrm{NiMo}+\mathrm{ZnO}^{\mathrm{h}}$ & 99.3 & 33.3 & 39.4 & 12.3 & 7.6 & 33.5 & 7.2 \\
\hline 9 & $\mathrm{Pt} / \mathrm{Al}_{2} \mathrm{O}_{3}-\mathrm{Ru} / \mathrm{Al}_{2} \mathrm{O}_{3}(1.0)^{\mathrm{i}}$ & 51.2 & 20.1 & 28.1 & 7.2 & 12.4 & 39.2 & 13.1 \\
\hline
\end{tabular}

Reaction conditions: $T=508 \mathrm{~K}, p_{\mathrm{Ar}}=3.1 \mathrm{MPa}$, weight hourly space velocity (WHSV) $=1.2 \mathrm{~h}^{-1}$ (relative to NiMo if not specified), and $t=8 \mathrm{~h}$.

a Defined according to Ref. [16].

b Including $\mathrm{CO}_{2}$ and light alkanes.

cIncluding $\mathrm{CH}_{3} \mathrm{CHO}, \mathrm{CH}_{3} \mathrm{COCH}_{3}, \mathrm{CH}_{3} \mathrm{OH}, \mathrm{CH}_{3} \mathrm{CHOHCH}_{3}, \mathrm{CH}_{3} \mathrm{CH}_{2} \mathrm{CH}_{2} \mathrm{OH}, \mathrm{CH}_{3} \mathrm{COOH}, \mathrm{CH}_{3} \mathrm{CH}_{2} \mathrm{COOH}, \mathrm{CH}_{2} \mathrm{OHCH} 2 \mathrm{OH}$, and trace amount of undefined products.

d $\mathrm{ZnO}$ was evenly mixed with NiMo as a mixture catalyst. Mass ratio of $\mathrm{ZnO}$ to NiMo in bracket.

$\mathrm{e}$ WHSV $=1.44 \mathrm{~h}^{-1}$.

${ }_{\mathrm{f}} \mathrm{WHSV}=0.6 \mathrm{~h}^{-1}$ (relative to $\mathrm{ZnO}$ ).

$\mathrm{g} \mathrm{ZnO}$ was loaded into the reactor first followed by NiMo, allowing the reactant to contact with $\mathrm{ZnO}$ first.

${ }^{\mathrm{h}}$ Loading order was reverse to entry 7.

${ }^{i}$ Prepared according to Ref. [16]. Mass ratio of $\mathrm{Pt} / \mathrm{Al}_{2} \mathrm{O}_{3}$ to $\mathrm{Ru} / \mathrm{Al}_{2} \mathrm{O}_{3}$ in bracket. WHSV $=1.2 \mathrm{~h}^{-1}$ (relative to $\mathrm{Pt} / \mathrm{Al}_{2} \mathrm{O}_{3}$ and $\mathrm{Ru} / \mathrm{Al}_{2} \mathrm{O}_{3}$ ).

$49.6 \%$ with a fall of the selectivity for gas products from $40.9 \%$ to $16.5 \%$. Meanwhile, the selectivity for ethanol decreased from $13.5 \%$ to $5.3 \%$. These results clearly demonstrated that the APR of glycerol was suppressed and the hydrogenolysis of glycerol was promoted with the aid of the physically mixed ZnO. The yield of 1,2-PDO can be further improved to $52.0 \%$ at the WHSV of $1.44 \mathrm{~h}^{-1}$ (entry 5, Table 1), which exceeded substantially the results documented in the literature from the APR-hydrogenolysis of glycerol on some other catalysts [14-17,33].

On increasing the WHSV, Fig. 5(a) illustrates that the conversion of glycerol over the skeletal NiMo catalyst decreased drastically when the WHSV exceeded $1.2 \mathrm{~h}^{-1}$, while it decreased more slowly over the $\mathrm{ZnO}-\mathrm{NiMo}(2.0)$ mixture catalyst (Fig. 5(b)). In addition, before the maximum selectivity for 1,2-PDO $(52.7 \%)$ was reached at the WHSV of $1.44 \mathrm{~h}^{-1}$ over the $\mathrm{ZnO}-\mathrm{NiMo}(2.0)$ mixture catalyst, the selectivities for both acetol

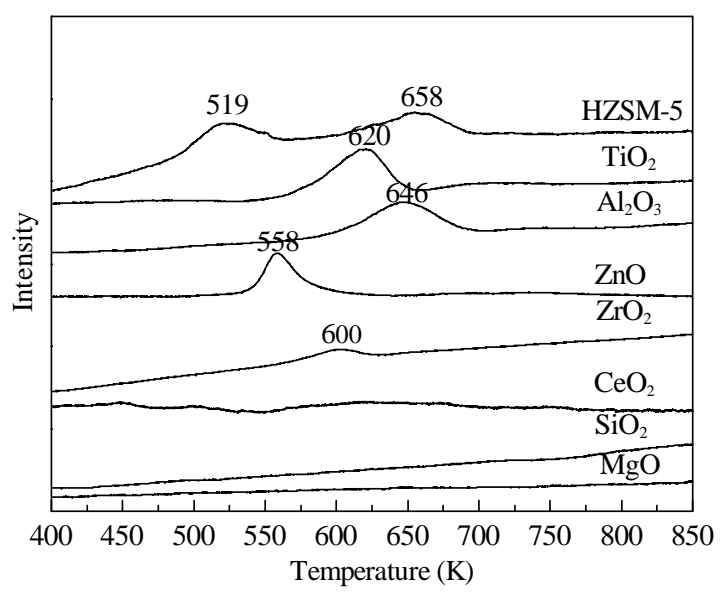

Fig. 3. $\mathrm{NH}_{3}$-TPD profiles of the oxides. and 1,2-PDO increased more with the WHSV than was the case with just the skeletal NiMo catalyst. This showed that the presence of $\mathrm{ZnO}$ favored both the dehydration of glycerol and the hydrogenation of acetol.

Table 2

Acid amounts on the oxides determined by $\mathrm{NH}_{3}$-TPD.

\begin{tabular}{lc}
\hline Sample & Acid amount $(\mathrm{mmol} / \mathrm{g})$ \\
\hline $\mathrm{HZSM}-5$ & 0.67 \\
$\mathrm{TiO}_{2}$ & 0.53 \\
$\mathrm{Al}_{2} \mathrm{O}_{3}$ & 0.44 \\
$\mathrm{ZnO}$ & 0.32 \\
$\mathrm{ZrO}_{2}$ & 0.12 \\
$\mathrm{CeO}_{2}$ & $\sim 0$ \\
$\mathrm{SiO}_{2}$ & 0 \\
$\mathrm{MgO}$ & 0 \\
\hline
\end{tabular}

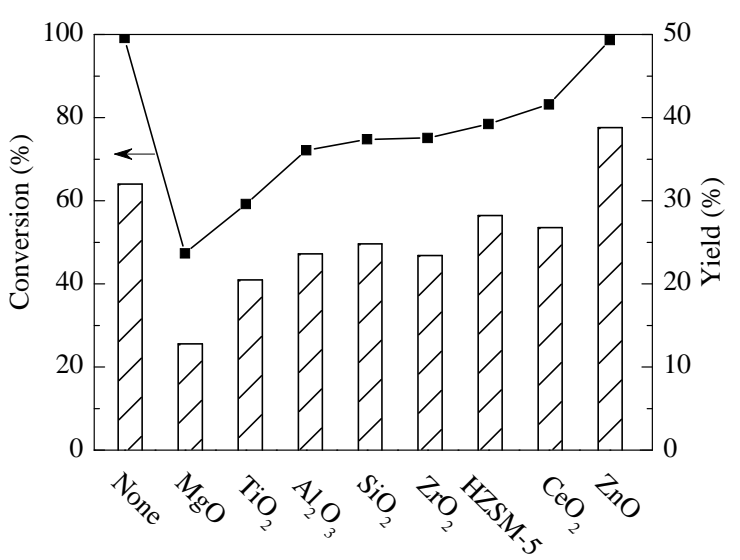

Fig. 4. Conversion of glycerol and yield of 1,2-PDO over oxide-NiMo mixture catalysts. Reaction conditions: oxide $/ \mathrm{NiMo}$ mass ratio $=0.5, T=$ $508 \mathrm{~K}, p_{\mathrm{Ar}}=3.1 \mathrm{MPa}, \mathrm{WHSV}=1.2 \mathrm{~h}^{-1}$ (relative to NiMo), and $t=8 \mathrm{~h}$. 

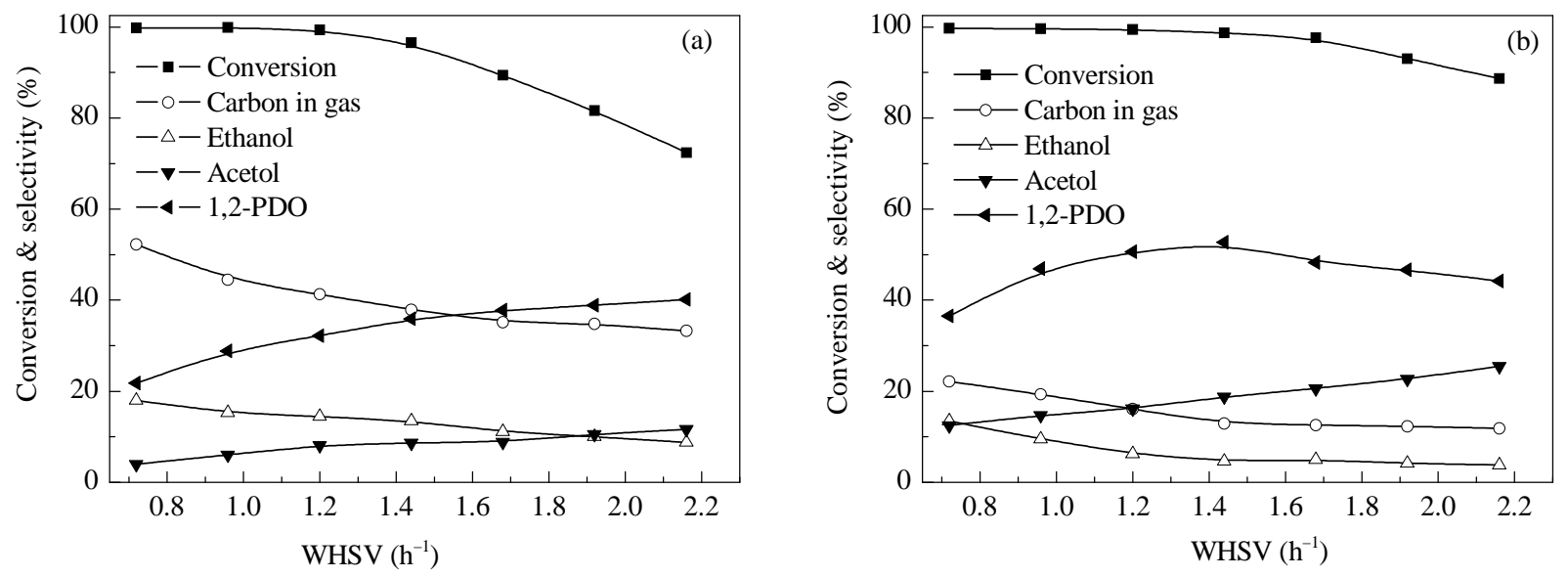

Fig. 5. Effect of WHSV (relative to NiMo) on the conversion of glycerol and product selectivity over skeletal NiMo catalyst (a) and $\mathrm{ZnO}-\mathrm{NiMo}(2.0)$ mixture catalyst (b). Reaction conditions: $0.50 \mathrm{~g} \mathrm{NiMo}, T=508 \mathrm{~K}$, and $p_{\mathrm{Ar}}=3.1 \mathrm{MPa}$. The mass ratio of ZnO/NiMo is $2.0 \mathrm{for}$ the $\mathrm{ZnO}-\mathrm{NiMo}(2.0) \mathrm{mixture}$ catalyst.

In order to further confirm the promoting effect of the physically mixed $\mathrm{ZnO}$ on the catalytic activity, comparative kinetic experiments at conversions of glycerol below $15 \%$ were conducted on the skeletal NiMo catalyst and the $\mathrm{ZnO}-\mathrm{NiMo}(2.0)$ mixture catalyst. As shown previously [34], transport limitation can be excluded under the present reaction conditions. Figure 6 presents the intrinsic activities of these two catalysts expressed as the turnover frequencies (TOFs) of glycerol conversion and 1,2-PDO production on the metallic Ni active sites. It should be emphasized that since the exact nature of the active sites on these catalysts is unclear, this comparison is only qualitative [35]. In Fig. 6, the higher TOF of glycerol over the $\mathrm{ZnO}-\mathrm{NiMo}(2.0)$ mixture catalyst than the skeletal NiMo catalyst ( 3.5 vs. $2.0 \mathrm{~min}^{-1}$ ) is consistent with the data in Fig. 5 that the former had a higher conversion of glycerol at higher WHSVs. The TOF of 1,2-PDO is $1.6 \mathrm{~min}^{-1}$ over the $\mathrm{ZnO}-\mathrm{NiMo}(2.0) \mathrm{mix}-$ ture catalyst, which is more than twice that over the skeletal NiMo catalyst $\left(0.72 \mathrm{~min}^{-1}\right)$. It is notable that the TOF of 1,2-PDO on the $\mathrm{ZnO}-\mathrm{NiMo}(2.0)$ mixture catalyst is comparable to that over a noble $\mathrm{Pt} / \mathrm{Al}_{2} \mathrm{O}_{3}$ catalyst [17].

In a recent work [16], a noble $\mathrm{Pt} / \mathrm{Al}_{2} \mathrm{O}_{3}-\mathrm{Ru} / \mathrm{Al}_{2} \mathrm{O}_{3}$ mixture catalyst (1:1, mass ratio) was found to be effective in the APR-hydrogenolysis of glycerol in a batch autoclave under $\mathrm{N}_{2}$.

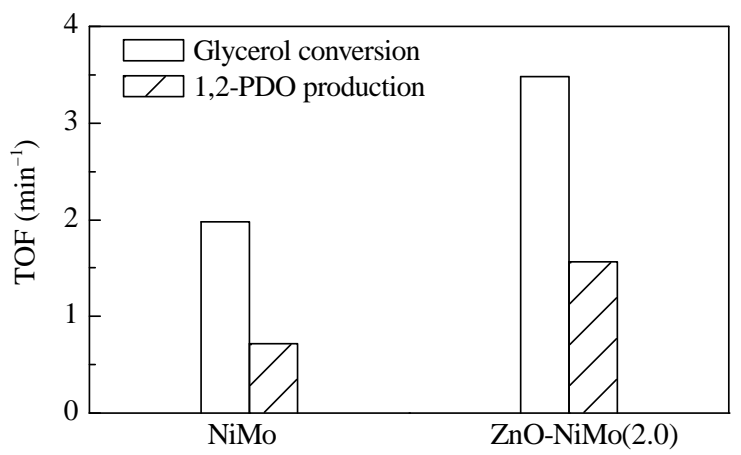

Fig. 6. TOFs of glycerol conversion and 1,2-PDO production for the skeletal NiMo catalyst and the $\mathrm{ZnO}-\mathrm{NiMo}(2.0)$ mixture catalyst in the APR-hydrogenolysis of glycerol. Reaction conditions: $T=508 \mathrm{~K}, p_{\mathrm{Ar}}=$ 3.1 MPa, and WHSV (relative to NiMo) of $7.2 \mathrm{~h}^{-1}$ for the skeletal NiMo catalyst and $10.8 \mathrm{~h}^{-1}$ for the $\mathrm{ZnO}-\mathrm{NiMo}(2.0)$ admixture catalyst.
We also prepared this mixed catalyst and evaluated it on our flow reactor under reaction condition identical to that for the ZnO-NiMo mixture catalysts. As compared to the $\mathrm{Pt} / \mathrm{Al}_{2} \mathrm{O}_{3}-\mathrm{Ru} / \mathrm{Al}_{2} \mathrm{O}_{3}$ mixture catalyst (entry 9, Table 1), the skeletal NiMo catalyst and all three ZnO-NiMo catalysts were more active, and the selectivities for 1,2-PDO on the $\mathrm{ZnO}-\mathrm{NiMo}(1.0)$ and $\mathrm{ZnO}-\mathrm{NiMo}(2.0)$ catalysts were also substantially higher at much higher conversions of glycerol.

\subsection{The promotion mechanism of $\mathrm{ZnO}$}

To study the promoting effect of $\mathrm{ZnO}$ in the $\mathrm{ZnO}$-NiMo mixture catalysts, control experiments were designed and conducted. First, we confirmed that $\mathrm{ZnO}$ alone was inactive in the transformation of glycerol (entry 6, Table 1). Second, instead of homogeneously mixing $\mathrm{ZnO}$ with NiMo, we placed them in two different sequences in the tubular reactor. In one situation, NiMo was loaded first, followed by $\mathrm{ZnO}$. In the other situation, a reversed loading sequence was adopted. The differences in terms of both glycerol conversion and product distribution between these two situations (entries 7 and 8, Table 1) and when just the skeletal NiMo catalyst was used (entry 1, Table 1) were negligible. This clearly demonstrated that $\mathrm{ZnO}$ was effective only when it was homogeneously mixed with NiMo, suggesting a synergistic effect between these two catalyst components.

In the literature, the Lewis acid catalyzed dehydration of glycerol to acetol is well documented [36-38]. Metal oxides such as $\mathrm{Zn}(\mathrm{II})-\mathrm{Cr}(\mathrm{III})$ mixed oxides [37] and $\mathrm{Nb}_{2} \mathrm{O}_{5}$ [9] are good catalyst/cocatalyst for the dehydration/hydrogenolysis of glycerol to acetol/1,2-PDO. Moreover, as proposed by Gallezot et al. [39], the Lewis acid polarizes the $\mathrm{C}=0$ group by accepting the lone pair electron on the oxygen end of the $\mathrm{C}=0$ group. This polarization favors a nucleophilic attack on the carbon atom in $\mathrm{C}=\mathrm{O}$ by hydrogen dissociatively adsorbed on an adjacent metallic $\mathrm{Ni}$ site, which facilitates the hydrogenation of acetol to 1,2-PDO. Thus, the Lewis acid sites are believed to be active in the hydrogenolysis of glycerol in both the dehydration and hydrogenation steps. 
However, according to the $\mathrm{NH}_{3}$-TPD profiles of the oxides (Fig. 3) and the acid amounts derived from the $\mathrm{NH}_{3}$-TPD profiles (Table 2), both the acid amount and acid strength of $\mathrm{ZnO}$ are only average among these oxides. On the other hand, it is worth noting that in a combined surface chemistry and theoretical study, Wang et al. $[40,41]$ substantiated that the Lewis acidity of $\mathrm{ZnO}$ can be enhanced in the presence of $\mathrm{CO}_{2} . \mathrm{CO}_{2}$ is chemisorbed on $\mathrm{ZnO}$ and forms a stable tridentate carbonate on the nonpolar (1010) surface of $\mathrm{ZnO}$, in which the carbon atom of $\mathrm{CO}_{2}$ bonds to one surface oxygen anion, and both oxygen atoms of $\mathrm{CO}_{2}$ form equivalent bonds with neighboring zinc cations. This adsorption mode occurs on every second zinc cation, resulting in both occupied and unoccupied surface zinc sites. The charge-accepting chemisorbed $\mathrm{CO}_{2}$ makes the unoccupied $\mathrm{Zn}$ cation more positive, thus enhancing the Lewis acidity of the unoccupied surface zinc cations [29]. The enhancement of Lewis acidity by $\mathrm{CO}_{2}$ chemisorption has also been observed on polycrystalline $\mathrm{ZnO}$ powder [40-43]. In the one-pot APR-hydrogenolysis of glycerol over the $\mathrm{ZnO}$-NiMo mixture catalysts, $\mathrm{CO}_{2}$ is one of the main APR products. So, it can be proposed that a $\mathrm{CO}_{2}$-enhanced Lewis acidity of $\mathrm{ZnO}$ occurred on the $\mathrm{ZnO}$-NiMo mixture catalysts, and that this was responsible for the synergistic effect between $\mathrm{ZnO}$ and NiMo and the enhanced conversion of glycerol and selectivity to 1,2-PDO.

Finally, we would like to comment on the atomic economy of the one-pot APR-hydrogenolysis of glycerol to 1,2-PDO over the ZnO-NiMo mixture catalysts. Referring to Scheme 1, the ideal APR/hydrogenolysis ratio of glycerol is 1:7 [15]. Following the classification of the products by Gandarias et al. [14], in Fig. 7 we plotted the evolution of the ratio between the selectivities to hydrogenolysis products and APR products versus the weight ratio of $\mathrm{ZnO}$ to NiMo. It is clear that by increasing the $\mathrm{ZnO} / \mathrm{NiMo}$ ratio from 0 to 2.0, the hydrogenolysis/APR ratio increased from 1.0 to 4.6 at the WHSV of $1.2 \mathrm{~h}^{-1}$. On further increasing the WHSV to $1.44 \mathrm{~h}^{-1}$ over the $\mathrm{ZnO}-\mathrm{NiMo}(2.0)$ mixture catalyst, the hydrogenolysis/APR ratio was 6.3 , which approached the ideal ratio. From the product distribution in Table 1, further catalyst or process improvement should focus on suppressing the breaking of the $\mathrm{C}-\mathrm{C}$ bond in glycerol which

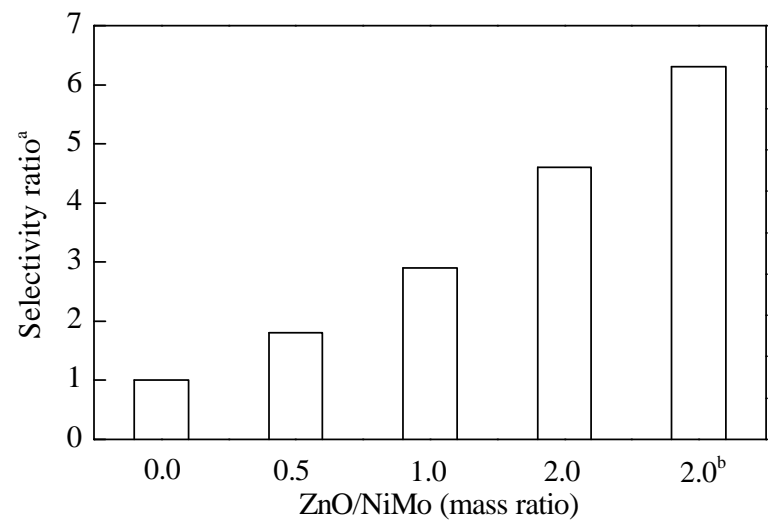

Fig. 7. Effect of mass ratio of $\mathrm{ZnO} / \mathrm{NiMo}$ on the ratio of hydrogenolysis products to APR products. Reaction conditions: $T=508 \mathrm{~K}, p_{\mathrm{Ar}}=3.1 \mathrm{MPa}$,

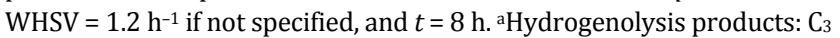
products in the liquid phase; APR products: $\mathrm{CO}_{2}$ and light alkanes. bWHSV $=1.44 \mathrm{~h}^{-1}$. mainly results in ethanol and other $\mathrm{C}_{2}$ liquid byproducts, and on enhancing the hydrogenation of the dehydration intermediate acetol to 1,2-PDO.

\section{Conclusions}

In the one-pot APR-hydrogenolysis of glycerol to 1,2-PDO in a continuous flow fixed bed reactor, physically mixed $\mathrm{ZnO}$ helps suppress excessive APR of glycerol and enhances the hydrogenolysis of glycerol. With the optimal $\mathrm{ZnO}-\mathrm{NiMo}(2.0)$ mixture catalyst, a yield of 1,2-PDO of $52.0 \%$ was achieved in the absence of externally supplied $\mathrm{H}_{2}$, and at a reaction pressure lower than that required for the hydrogenolysis of glycerol under $\mathrm{H}_{2}$. The remarkable synergistic effect between the mixed $\mathrm{ZnO}$ and NiMo is attributed to $\mathrm{CO}_{2}$-enhancement of the Lewis acidity of $\mathrm{ZnO}$, which promotes the dehydration of glycerol to acetol and the hydrogenation of the latter to 1,2-PDO. This work opens a new avenue for the continuous production of 1,2-PD0 from glycerol and water over a non-noble metal catalyst under mild reaction conditions.

\section{References}

[1] Pagliaro M, Ciriminna R, Kimura H, Rossi M, Pina C D. Angew Chem, Int Ed, 2007, 46: 4434

[2] Bienholz A, Schwab F, Claus P. Green Chem, 2010, 12: 290

[3] Cortright R D, Sanchez-Castillo M, Dumesic J A. Appl Catal B, 2002, 39: 353

[4] Lahr D G, Shanks B H.J Catal, 2005, 232: 386

[5] Maris E P, Ketchie W C, Murayama M, Davis R J. J Catal, 2007, 251: 281

[6] Zhou J X, Guo L Y, Guo X W, Mao J B, Zhang S G. Green Chem, 2010, 12: 1835

[7] Lee S, Moon D J. Catal Today, 2011, 174: 10

[8] Miyazawa T, Koso S, Kunimori K, Tomishige K. Appl Catal A, 2007, 329: 30

[9] Balaraju M, Rekha V, Prasad P S S, Devi B L A P, Prasad R B N, Lingaiah N. Appl Catal A, 2009, 354: 82

[10] Gandarias I, Arias P L, Requies J, El Doukkali M, Güemez M B. J Catal, 2011, 282: 237

[11] Miyazawa T, Kusunoki Y, Kunimori K, Tomishige K. J Catal, 2006, 240: 213

[12] Vasiliadou E S, Heracleous E, Vasalos I A, Lemonidou A A. Appl Catal B, 2009, 92: 90

[13] Mane R B, Ghalwadkar A A, Hengne A M, Suryawanshi Y R, Rode C V. Catal Today, 2011, 164: 447

[14] Gandarias I, Arias P L, Requies J, Guemez M B, Fierro J L G. Appl Catal B, 2010, 97: 248

[15] D’Hondt E, de Vyver S V, Sels B F, Jacobs P A. Chem Commun, 2008: 6011

[16] Roy D, Subramaniam B, Chaudhari R V. Catal Today, 2010, 156: 31

[17] Wawrzetz A, Peng B, Hrabar A, Jentys A, Lemonidou A A, Lercher J A. J Catal, 2010, 269: 411

[18] Hu J Y, Liu X Y, Wang B, Pei Y, Qiao M H, Fan K N. Chin J Catal (胡基 业，刘晓钰，王彬，裴燕，乔明华，范康年. 催化学报), 2012, 33: 1266

[19] Chu X W, Liu J, Qiao M H, Zhuang J H, Fan K N, Zong B N, Zhang X X. Chin J Catal (褚娴文, 刘俊, 乔明华, 庄继华, 范康年, 张晓昕, 宗 保宁. 催化学报), 2009, 30: 595

[20] Hu H R, Qiao M H, Wang S, Fan K N, Li H X, Zong B N, Zhang X X. 


\title{
Graphical Abstract
}

Chin. J. Catal., 2013, 34: 1020-1026 doi: 10.1016/S1872-2067(12)60543-9

\section{Physically mixed ZnO and skeletal NiMo for one-pot reforming-hydrogenolysis of glycerol to 1,2-propanediol}

HU Jiye, LIU Xiaoyu, FAN Yiqiu, XIE Songhai, PEI Yan, QIAO Minghua*, FAN Kangnian, ZHANG Xiaoxin, ZONG Baoning*

Fudan University; Research Institute of Petroleum Processing

Physically mixing $\mathrm{ZnO}$ with skeletal $\mathrm{Ni}_{40} \mathrm{Mo}_{10}$ gave an excellent catalyst for the hydrogenolysis of glycerol to 1,2-PDO under an inert atmosphere, which was due to $\mathrm{CO}_{2}$-enhancement of the Lewis acidity of $\mathrm{ZnO}$ by $\mathrm{CO}_{2}$ generated from the reforming of glycerol.

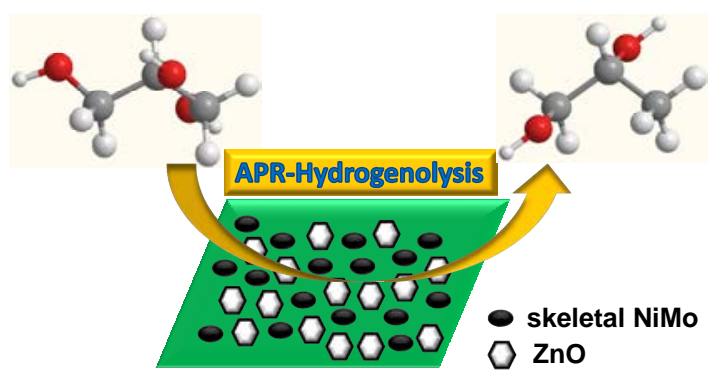

X L, Tsang S C. Angew Chem, Int Ed, 2011, 50: 2162

[32] Ridalgo B, Arenillas A, Menéndez J Á. Appl Catal A, 2010, 390: 78

[33] Yin A Y, Guo XY, Dai W L, Fan K N. Green Chem, 2009, 11: 1514

[34] Xie F Z, Chu X W, Hu H R, Qiao M H, Yan S R, Zhu Y L, He H Y, Fan K N, Li H X, Zong B N, Zhang X X. J Catal, 2006, 241: 211

[35] Boudart M. Chem Rev, 1995, 95: 661

[36] Chai S H, Wang H P, Liang Y, Xu B Q. Green Chem, 2007, 9: 1130

[37] Alhanash A, Kozhevnikova E F, Kozhevnikov I V. Appl Catal A, 2010, 378: 11

[38] Katryniok B, Paul S, Bellière-Baca V, Reye P, Dumeignil F. Green Chem, 2010, 12: 2079

[39] Gallezot P, Cerino P J, Blanc B, Flèche G, Fuertes P. J Catal, 1994, 146: 93

[40] Wang Y M, Kováčik R, Meyer B, Kotsis K, Stodt D, Staemmler V, Qiu H S, Traeger F, Langenberg D, Muhler M, Wöll C. Angew Chem, Int Ed, 2007, 46: 5624

[41] Wang Y M, Xia X, Urban A, Qiu H S, Strunk J, Meyer B, Muhler M, Wöll C. Angew Chem, Int Ed, 2007, 46: 7315

[42] Noei H, Wöll C, Muhler M, Wang Y M. Appl Catal A, 2011, 391: 31

[43] Noei H, Wöll C, Muhler M, Wang Y M. J Phys Chem C, 2011, 115: 908

\section{ZnO与骨架NiMo物理混合用于丙三醇催化重整-氢解制 $1,2-$-丙二醇}

\author{
胡基业 ${ }^{\mathrm{a}}$, 刘晓铿 ${ }^{\mathrm{a}}$, 范义秋 ${ }^{\mathrm{a}}$, 谢颂海 ${ }^{\mathrm{a}}$, 裴 燕 ${ }^{\mathrm{a}}$, 乔明华 ${ }^{\mathrm{a},{ }^{*}}$, 范康年 ${ }^{\mathrm{a}}$, 张晓昕 ${ }^{\mathrm{b}}$, 宗保宁 ${ }^{\mathrm{b}, \#}$ \\ 复旦大学化学系上海市分子催化和功能材料重点实验室, 上海 200433 \\ b中国石油化工股份有限公司石油化工科学研究院催化材料和反应工程国家重点实验室, 北京 100083
}

\begin{abstract}
摘要: 以骨架NiMo以及与氧化物物理混合, 考察了其在连续固定床反应器中无外加氢气条件下的丙三醇一锅法重整-氢解制 $1,2-$ 丙二醇(1,2-PDO)的性能. 研究发现, 骨架 NiMo 自身催化活性高, 但对 1,2-PDO 的选择性一般. 当将其与 $\mathrm{MgO} \mathrm{SiO}_{2}, \mathrm{Al}_{2} \mathrm{O}_{3}$, $\mathrm{HZSM}-5, \mathrm{TiO}_{2}, \mathrm{ZrO}_{2}$ 或CeO 2 机械混合时, 丙三醇转化率和1,2-PDO选择性均发生下降. 但当与 $\mathrm{ZnO}$ 物理混合时, 催化活性和选择性 均有所提高, 1,2-PDO得率可达 $52.0 \%$, 优于贵金属催化剂在该一锅法反应中得到的结果. 物理混合的ZnO与骨架NiMo之间这种 独特的协同作用, 归因于重整过程中产生的 $\mathrm{CO}_{2}$ 在 $\mathrm{ZnO}$ 上发生化学吸附, 原位增强了 $\mathrm{ZnO}$ 的路易斯酸性. 这不仅促进了丙三醇在 $\mathrm{ZnO}$ 上脱水生成中间产物丙酮醇, 也促进了丙酮醇在骨架NiMo上加氢生成1,2-PDO.
\end{abstract}

关键词: 丙三醇; 氢解; 氧化锌; 镍; 钼; 协同效应

收稿日期: 2012-12-20. 接受日期: 2013-01-29. 出版日期: 2013-05-20.

*通讯联系人. 电话: (021)55664679; 传真: (021)55665701; 电子信箱: mhqiao@fudan.edu.cn

\#通讯联系人. 电话/传真: (010)82368011; 电子信箱: zongbn.ripp@sinopec.com

基金来源：新世纪优秀人才支持计划(NCET-08-0126); 国家重点基础研究发展计划(973计划, 2012CB224804); 国家自然科学基 金(21073043); 上海市科委项目(10JC1401800, 08DZ2270500); 上师大上海市稀土功能材料重点实验室开放课题.

本文的英文电子版由Elsevier出版社在ScienceDirect上出版(http://www.sciencedirect.com/science/journal/18722067). 